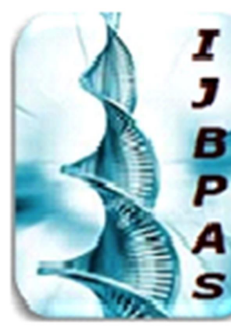

International Journal of Biology, Pharmacy and Allied Sciences (IJBPAS)

'A Bridge Betuen Caboratory and QRendo'

Www.iibpas.com

\title{
TO ELABORATE THE CONCEPT OF AGNI DUSHTI IN THE PATHOGENESIS OF VARIOUS DISORDER - A REVIEW
}

\section{JYANI HP ${ }^{1}$, DAHILEKAR SG ${ }^{2 *}$, DAHILEKAR H $^{3}$ AND MALVIYA G ${ }^{4}$}

1: Final Year PG Scholar, Department of PG and PHD studies in Roga Nidana, Parul

Institute of Ayurveda, Parul University, Limda, Vadodara, Gujarat - 391760

2: Professor, Department of PG and PHD studies in Roga Nidana, Parul Institute of Ayurveda, Parul University, Limda, Vadodara, Gujarat - 391760

3: Professor, Department of PG and PHD studies in Roga Nidana, Parul Institute of Ayurveda and Research, Parul University, Limda, Vadodara, Gujarat - 391760

4: Final Year PG Scholar, Department of PG and PHD studies in Roga Nidana, Parul

Institute of Ayurveda, Parul University, Limda, Vadodara, Gujarat - 391760

*Corresponding Author: Dr. Sandeep G. Dahilekar: E Mail: sandeep dahilekar@rediffmail.com

Received 12 ${ }^{\text {th }}$ Dec. 2021; Revised 14 ${ }^{\text {th }}$ Jan. 2022; Accepted $7^{\text {th }}$ Feb. 2022; Available online $5^{\text {th }}$ March 2022

https://doi.org/10.31032/IJBPAS/2022/11.3.1047

\begin{abstract}
The term Agni, in common language means fire. In the context of the functioning of a living organism, which maintains its integrity and performs its vital activities, by converting - in Pakadi Karmas or bio-physical and bio- chemical processes- the food consumed in various way - Ashita, Khadita etc, not only into its various structural and functional constituents but also to provide the energy necessary for proceeding of innumerable vital activities. In Ayurveda Agni is said to be the Moola in the development of every disease. Vitiation of Agni leads to the development of Ama which is the basic element in the pathogenesis of every disease as explained by Vagbhatta. Aam rasa utpatti results in the formation of vitiated Utrotar Dhatus and consequently development of Vikaras of particular Dhatus. In this review article I am trying the establish the role of Agni in the pathogenesis of Vikaras.
\end{abstract}

Keywords: Agni, Jatharagni, Kayagni, Dhatwagni, Amadosha, Ama, Vata, Pitta, Kapha, Purisha etc. 


\section{INTRODUCTION}

According to Nyaya-Vaisesika, Tejas in which Agni is implicit is one of the Navadravyas and it is represented by Tejasparamanu. Agni in Ayurveda, is reflected in the concept of Pitta of this system. ${ }^{(1)}$ The term Pitta is derived the root 'tap'- to heat or to burn. ${ }^{(2)}$ This term is seen to have three meanings viz., Tap Aishavarye (refers to that factor which is responsible to make one achieve the eight kinds of benefits), Tap Daahe (relates to the act of burning of the nutrition consumed), and Tap Santaape (refers to the generation of heat).

From the point of view of Ayurveda, Pitta has been described as Agni (fire), since it performs fire-like actions i.e. Paaka, which refers to Pachan (digestion), Dahan (burning combustion or oxidation) including Bhinna Samghata (splitting); Tapana (heat production), Parinamana (conversion), Paravrtti (transformation), Prakasana (illumination), Ranjan or Varnakara (colouration) and Prabhakara (to cause lustre).

In general sense, the term Kaaya or body itself has been equated to Agni. ${ }^{(3)}$

Acharya Charaka has recorded Marici as having stated that "it is only Agni, which is located in Pitta, that gives rise to beneficial or adverse consequences according as it is in normal or abnormal state of functioning. ${ }^{(4)}$

The concept of Agni of Ayurveda, which refers to the manifold functions ascribed to Pitta is at once comprehensive. It not only includes chemical agencies responsible for Aharapacana in the Kostha (corresponding to gastro-intestinal digestion), which leads to separation of Sarabhaga (nutrient fraction) of the Ahara (food) from $K_{\text {Kittabhaga }}{ }^{(5)}$ (the indigestible or undigested residue of the food) but also metabolic events - energy, synthesis and maintenance metabolism. In addition, it is seen to comprehend photo and chemo synthetic processes.

Aim: To elobrate to role of Agni Dushti in pathogenesis of various disorder

Objectives: To establish the role and functional utility of Agni in the development of Vyadhi (disease) with basic fundamental principle and theory of Ayurveda

MATERIAL AND METHODS: We used Charak Samhita, Sushrut Samhita and Astang Hradaya, which all are based literature of Ayurveda as well as other Ayurveda literature and other authentic reference book of Ayurveda and morden medicines for understand and justification of this concept of agni and their concept. 


\section{DISCUSSION}

Pachakpitta and Agni -

Pachakapitta known variously as

Jatharagni, Kosthagni, Antaragni,

Pachkagni and Dehagni etc; while being located in its own place in an area between Amasaya and Pakvashaya, directly participates in the digestion of food and at the same time, lends support to and augments the functions of the remaining Pittas, present elsewhere in the body. ${ }^{(6)}$ The reference here, obviously relates to the remaining Pittas vis., Ranjaka, Sadhaka, Alochaka and Bhrajaka. It is held that the Pachakpitta contributes moieties of itself to the seven Dhatvagnis, and supports and augments the function of the latter. ${ }^{(7)}$

The facts reviewed above represent but one aspect of the concept of Pachakagni or Pachaka Pitta which may have to be studied with the structure known as Grahani vis-a-viz, Pitta Dhara Kala, described both by Acharya Sushruta and Vagbhata. There still remains another and perhaps, a major aspect of this concept, which is of fundamental importance. It relates to the observation made by all the three main authors of Ayurveda (Vrddhatrayi) that Antaragni contributes to and augments the functions of other Agnis, which are found elsewhere, in the body. They are all derived from it. Their activities or otherwise, are dependent upon an increase or decrease as the case may be of Jatharagni. ${ }^{\left({ }^{2}\right.}$

Says Susruta, "by a dispensation which is unseen (a cause which can not be perceived or explained and which is hidden), Pitta which is located in an area between Amashaya and Pakwashaya, is responsible for the digestion of four kinds of food ingested by living beings and the elimination of the residue in the form of urine and faeces after the completion of the process. Located as it is in its own place (between Amashaya and Pakwashaya) it contributes to and augments the functions of other locations of Pittas, in the performance of action. This Pitta is, therefore, spoken of as Pachakagni. ${ }^{(9)}$

\section{Mahasrotas and Kostha -}

According to Ayurveda, the Mahasrotas, corresponding to the alimentary tract, is immediately concerned with the process of alimentation (ingestion and egestion). Mahasrotas is also spoken of as Kostha. It may be noted here, that the term Koshtha has several synonyms, such as Mahasrotas (the great channel), Sarira Madhya (the middle portion of the body or trunk), Mahanimna (the great cavity), Amapakvasaya (the organ of preliminary and final aspect of digestion) and Abhyantararogamarga (internal pathway of disease). ${ }^{(10)}$ 
Avasthapaka -

Avasthapaka refers to changes, which Aharadravyas undergoin the Koshtha. Two phases of it have benn described viz. Prapaka and Vipaka. Prapaka has been defined as Prathamapaka or the first outcome of Paka or chemical action. Vipaka has benn defined as the outcome of the action of Jatharagni on the Ahara substrate - the resultant and previous Paka. $^{(1)}$, i.e. Prathama Paka, which is to be judged from the point of view of the taste of the end products of gastrointestinal digestion viz., Madhura (sweet), Amla (sour) and Katu (Pungent).

\section{Four types of Agni -}

Four kinds of functional states of Agni, according as to the Dosha or Doshas which may influence it has benn envised.

a) Mandagni: This is a state in which the action of Jatharagni is considerably inhibited due to the dominant influence of Kapha, of the three Doshas. Hence, this state of the Agni is known as Mandagni. In this state, the Agni is unable to digest (and metabolise) even a small quantity of otherwise even easily digestable food.

(b) Tikshnagni - The action of Jatharagni, in this state, is influenced predominantly by Pitta, of the three Doshas. The Agni, in this condition, is said to be excessively excited and, hence it is known as Tikshnagni. Tikshnagni easily digests even a very heavy meal, in a very short space of time. It causes voracious hunger- a condition usually spoken of as Atyagni (or Bhasmaka by certain authorities). It makes it possible for a glutton to digest his all too frequent meals. It is started to produce parched throat, palate and lips, heat and other discomforts.

(c) Vishamagni - An erratic state of the Agni arises as a result of the influence of Vata, in the condition described as Vishamagni. In this state, the action of Agni is irregular and fitful. It sometimes helps the process of complete digestion and at other times, produces distension of the abdomen, colicky pain, constipation of the bowel dysentery, ascites, heaviness of the limbs and loose-motions.

(d) Samagni - In the well-equilibrated state of the functioning of Tridoshas, the Jatharagni is also stated to functioning normally. This state of its function has been described as Samagni. In other words, Jatharagni ensures complete digestion of the food ingested at the proper time without any irregularity, when Tridoshas are in an equilibrated state of functioning.

Of the above, Vishamagni is stated to cause various kinds of Vatik diseases; Tikshnagni, different kinds Pittaja diseases and Mandagni, varieties of Kaphaja diseases.

Amadosha and Agni - 
In the Ayurvedic view, an early all diseases, included under Kayachikitsa, have their origin in Amadosha. Amadosha and Amavisha are conditions which are stated to ocuur due to the impairment of Kayagni. It was seen earlier that the Kayagni, in its narrower sense relates to factors concerned with gastro-intestinal digestion and in its wider sense to metablic events of the body. Amadosha or Amavisha both as acute and sub acute or chronic conditions appear to relate to the gastro-intestinal as well as metabolic disturbanes engendered due to the impairment of Antaragni or better still Agnidushti. The basic doctrines of Ayurveda as regards health and disease revolve round nutrition and its utilization by the body under the influence of Agni. Its theories of pathogenesis are also co-related to the type of nutrition available and the functional states of Agni. Generally speaking, Ama has been defined as a condition in which the first Hetu, namely Rasa is not properly formed due to the lowered strength of Usma (Agni). ${ }^{(12)}$

On the other hand, in this state, the food ingested becomes Dusta. According to other authorities, quoted by Vagbhata, the impaired Vatadi Doshas become mixed up with one another, leading to the formation of Amadosha, very much like the production of Visha from the spoiled Kodrava. ${ }^{(13)}$
The general outlook of the two descriptions of Amadosha would appear to be that in the absence of or due to the inhibition of Kayagni the ingested food is not properly digested. Products which arise out of such an impaired digestion is retained in the Amashaya and they undergo such changes as yield toxic substances which are known as Ama.

The etiological factor of Amadosha as described by Charak and Sushrut are the following and this range from dietetic indiscretions including errors of nutrition to emotional tensions of different kinds. ${ }^{(14)}$

The aetiological factors mentioned above part, note has to be taken of several definitions an descriptions of Amadosha furnished by Vijayarashita in his Madhukosa commentary on Madhava Nidana.

"The term Annarasa means Ama. If Annarasa is not properly digested and formed, then the outcome of such a digestion is known as $A m a$ ". There are others who hold that the undigested Annarasa possessing foul odour and excessive pastiness deprives the body of its nutrition and in consequence causes sadana. This is known as Ama. ${ }^{(15)}$
AMA FORMATION DUE TO DHATWAGNI MANDYA
It is seen that Dalhana ${ }^{(16)}$ and Chakrapani $^{(17)}$ in their commentaries on 
Susruta have stated that the formation of Ama need not necessarily be due to Jatharagni Mandhya only, and it may also occur due to the impairment of Dhatwagnivyapara. It is also seen from Atankadarpana commentary of Madhavanidana that Amadosha may be caused due to Mandya of Dhatwagnis and Bhutagnis, on account of which Sosa, Vran, Vidradhi and such other diseases may be caused. It is necessary to bear in mind at this point that the term Dhatu used in this context by Dalhana, Cakrapani and Vacaspativaidya refer to Ashayi or Poshaka Dhatus are Pachakamsas. While
Jatharagni Paka refer to digestive events, the Dhatvagni Paka relates to intermediary metabolism and Pakas carried out by these Pachakmasas in Sthayi Dhatus relates to the synthetic and maintenance metabolism in them.

The Vaisamya of Dhatvagni referred to by Dalhana, Cakrapani and Vacaspativaidya, leads to the impairment of intermediary metabolism resulting in the production of incompletely metabolized substances which are obviously not fit for utilization by the Sthayi Dhatus. Thus these products are in Ama state and cause Amadosa at this level.

NORMAL AND ABNORMAL DIAGNOSTIC EVENTS IN DIFFERENT PARTS OF KOSTHA AND CORRESPONDING SYMPTOMATOLOGY

\begin{tabular}{|c|c|c|c|c|}
\hline Organ & Normal Function & $\begin{array}{c}\text { Abnormal } \\
\text { function }\end{array}$ & $\begin{array}{c}\text { Symptoms in abnormal } \\
\text { function }\end{array}$ & Diseases \\
\hline $\begin{array}{c}\text { Urdhva } \\
\text { Amashaya }\end{array}$ & $\begin{array}{c}\text { Madhur Avastha } \\
\text { paka, } \\
\text { Bhinnasamghata, } \\
\text { Annamardava } \\
\text { karan }\end{array}$ & $\begin{array}{c}\text { Suktapaka } \\
\text { (Fermentation), } \\
\text { Apakvanna (non } \\
\text { digestion of food) }\end{array}$ & $\begin{array}{c}\text { Guruta or heaviness, } \\
\text { Utkleda, Ganda and } \\
\text { Akshikuta Sotha, Udgara, } \\
\text { Avidagdha-Pravartana }\end{array}$ & $\begin{array}{c}\text { Amajirna, } \\
\text { Chaardi, } \\
\text { Urdhvag } \\
\text { Amlapitta, } \\
\text { Agnimandya, } \\
\text { etc }\end{array}$ \\
\hline $\begin{array}{c}\text { Adho } \\
\text { Amashaya }\end{array}$ & $\begin{array}{c}\text { Amla Avastha Paka, } \\
\text { Rasasosana, } \\
\text { Sarakitta- } \\
\text { Vibhajana }\end{array}$ & $\begin{array}{c}\text { Apakvnna (Non } \\
\text { digestion of food), } \\
\text { Ama formation, } \\
\text { Bahupicchila } \\
\text { (extreme } \\
\text { sliminess) }\end{array}$ & $\begin{array}{c}\text { Bhrama, Trt, Murcha, Osa, } \\
\text { Cosa, Daha }\end{array}$ & $\begin{array}{c}\text { Vidagdhajirna, } \\
\text { Trushna, } \\
\text { Vishuchika, } \\
\text { Adhoga } \\
\text { Amlapitta, } \\
\text { Udararoga etc }\end{array}$ \\
\hline Pakvasaya & $\begin{array}{c}\text { Drava-Sosana, } \\
\text { mala-Mutra } \\
\text { Vibhajana, } \\
\text { Pindikarana, Vayu- } \\
\text { upadana } \\
\text { Dravyotpatti, } \\
\text { malarupa Vayu } \\
\text { Pravartana }\end{array}$ & $\begin{array}{c}\text { Daurgandhya } \\
\text { (foul smell), } \\
\text { aidrava- Sosana, } \\
\text { Alpadrava Sosana, } \\
\text { Impaired } \\
\text { vibhajana, } \\
\text { Improper } \\
\text { Pindikarana, } \\
\text { formation of more } \\
\text { Vayu (Malarupa), } \\
\text { Less formation of } \\
\text { Upadana } \\
\text { Dhaturupa Vayu. }\end{array}$ & $\begin{array}{c}\text { Amla-udgara, Shula, } \\
\text { Adhmana, Toda, Bheda etc. } \\
\text { Mala Apravrtti, Vata } \\
\text { Apravrtti, Stambha, Moha, } \\
\text { Angapidana, Drava Mala } \\
\text { Pravartana,Ajasakrtvat } \\
\text { Mala Pravartana. }\end{array}$ & $\begin{array}{c}\text { Atisar, } \\
\text { Adhman, } \\
\text { Vibandha, } \\
\text { Anaha, } \\
\text { Pravahika, } \\
\text { Alasaka, } \\
\text { Vilambika } \\
\text { Udararoga etc. }\end{array}$ \\
\hline
\end{tabular}


SYMPTOMS PERTAINED TO URDHVA AND ADHOAMASAYA-DOSA WISE

\begin{tabular}{|c|c|c|}
\hline Vata & Pitta & Kapha \\
\hline $\begin{array}{c}\text { Tiktodgara (bitter ercation) } \\
\text { Sabda Pravala udgara } \\
\text { (eructation with great sound) } \\
\text { Saphena Chardi ( frohy } \\
\text { vomiting) } \\
\text { Vichina chardi ( vomiting wiith } \\
\text { splitted material) } \\
\text { Krsna Chardi (Coffee ground } \\
\text { vomiting) } \\
\text { Tanuka Chardi ( Thin vomiting) } \\
\text { Kasaya Chardi ( Astringent } \\
\text { vomiting) } \\
\text { Krchren chardi (painful } \\
\text { vomiting) } \\
\text { Alpa chardi (vomiting in less } \\
\text { quantities) } \\
\text { Bhukte svasthya ( a sense of ease } \\
\text { after taking meals) } \\
\text { Svasa (dyspnea) } \\
\text { Hrdrk (pre-cardial pain) } \\
\text { Amsark (pain in shoulder) } \\
\text { Hrdayadrava (palpitation) } \\
\text { Prstha sula (colicky pain in the } \\
\text { back) } \\
\text { Agnimandya (poor digestion) } \\
\text { Sukta paka (production of } \\
\text { organic acids at the time of } \\
\text { digestion) } \\
\text { Ksut (appetite) } \\
\text { Trusna (thirst) } \\
\text { Parsvaruk (pain in flanks) } \\
\text { Parikartika ( sawing pain) } \\
\text { Antra vikujana (sound in the } \\
\text { intestines) } \\
\text { Visamagni (impaired digestion) }\end{array}$ & $\begin{array}{c}\text { Puti udgara ( foul smelling } \\
\text { eructation) } \\
\text { Amla Udgara ( Acid eructation) } \\
\text { Vomiting of green, yellow, } \\
\text { red,black, coloured material } \\
\text { having sour and bitter in taste. } \\
\text { Usna vamana (hot vomiting) } \\
\text { Mamsodakabha vamana } \\
\text { (vomiting of fresh washed water) } \\
\text { Dhumra vamana (vomiting of } \\
\text { foamy substances) } \\
\text { Ksardakabha vamana } \\
\text { Hrt Daha ( burning sensation in } \\
\text { praecardial region) } \\
\text { Pipasa (thirst) } \\
\text { Vidaha (burning sensation in } \\
\text { epigastric area) } \\
\text { Avipaka (indigestion) } \\
\text { Ajirna sarana (voiding of } \\
\text { undigested material) } \\
\text { Vidaha (burning sensation) } \\
\text { Nabhidesa Daha ( burning } \\
\text { ensation umbilical region) } \\
\text { Jirjati sula (colicky ain during } \\
\text { igestion) }\end{array}$ & $\begin{array}{c}\text { Udgara Bahulya ( excessive } \\
\text { eructations) } \\
\text { Udgararodha (inhibition of } \\
\text { eructation) } \\
\text { Picchila Vamana (Slimy } \\
\text { vomiting) } \\
\text { Slesmayukta Vamana (mucoid } \\
\text { vomiting) } \\
\text { Sniigdha vaman(viscous } \\
\text { vomiting) } \\
\text { Ghana vamana (thick vomiting) } \\
\text { Svadu vamana (sweet vomiting) } \\
\text { Sukla vamana (white vomiting) } \\
\text { Sita vamana (cold vomiting) } \\
\text { Tantumat vamana (thread } \\
\text { vomiting) } \\
\text { Nisthivana (spitting) } \\
\text { Lavana Praseka ( saline } \\
\text { salivation) } \\
\text { Tanu praseka (thin salivation) } \\
\text { Kapha praseka (mucoid } \\
\text { salivation) } \\
\text { Utkleda (nausea) } \\
\text { Gurutva (heaviness) } \\
\text { Stimita kostha (silent gastro } \\
\text { intestinal tract) } \\
\text { Amasayark (pain in stomach) } \\
\text { Svasa (dyspnea) } \\
\text { Aggravation after in taking } \\
\text { meals. } \\
\text { Agnimandya (indigestion) }\end{array}$ \\
\hline
\end{tabular}

\begin{tabular}{|c|c|c|}
\hline \multicolumn{2}{|c|}{ SYMPTOMS PERTAINED TO PAKVASHAYA DOSA WISE } \\
\hline Vata & Pitta & Kapha \\
\hline $\begin{array}{c}\text { Characteristics of the stool } \\
\text { voided, are as follow- }\end{array}$ & Charateristics of the stool, voided & Bhinnamala (broken stool) \\
Drava (liquid) & are as follow- & Ama samsrata mala (wih \\
Suska (dry) & Nilabha (bluish) & undigested materials) \\
Tanu (thin) & Pitabha (yellowish) & Slesma samsrsta mala ( mucoid \\
Ama (undigested) & Puti (Putrified) & Guru (heavy) \\
Sabdavat (noisy) & Usma (Hot) & Pichila purisa (slimy stool) \\
Phenavat (frothy) & Drava (liquid) & Svet purisa (white stool) \\
Grathita (scybalus) & Rakta (bloody) & Snigdha mala (viscous stool) \\
Picchanugata (slimy) & Ama (with undigested food) & Tantumat Purisa (thread stool) \\
Krsna (tarry) & Harita (green) & Alpamala (voiding in less \\
Syava (brown) & Sambhinna (broken) & quantity) \\
Aruna (redish) & Prachura (in large quantity) & Krsna (Black) \\
Parusa (rough) & Sapravahika mala (voiding with \\
Vijjala (slimy) & Atidurgandhi (very foul smelling) & tenesmus) \\
Vipluta (which floats and & Others are - & Abhiksna mala frequent \\
spreads) & Vidaha (burning sensation) & motions) \\
Avasadi (which sinks and & Paka (proctits) & Vistambha (constipation) \\
spreads) & & Vanksananaha (distention of the \\
lower abdomen) \\
Amagandhi (having foul putrid & & Payu vikrsti (sucking of anus) \\
smell) & Nabhi vikrsti (sucking of \\
Modes/voiding are as follows- & & umbilicus) \\
cirat (delayed) & & Vastivikrsti (sucking of bladder) \\
Dubha (with difficulty) & Anubandha sula (continuity of \\
Muhurbaddha and muhurdrava & & colicky pain) \\
(sometimes hard and sometimes & & Sancayadupa vesana (sudden \\
\hline
\end{tabular}




\begin{tabular}{|c|c|}
\hline $\begin{array}{c}\text { liquid) } \\
\text { Stoka (in small quantities) } \\
\text { Sapravahika (with tenesmus) } \\
\text { Saruk (with pain) } \\
\text { Frequent motions other } \\
\text { characteristics - } \\
\text { Vit sanga (retention of faeces) } \\
\text { Vata sanga (retention of gas) } \\
\text { Atopa ( ainful distention with } \\
\text { sound } \\
\text { Anaha (flatulence) } \\
\text { Adhmana (tymphanitis) } \\
\text { Vistambha (constipation) } \\
\text { Uru-ruk } \\
\text { Kuksi ruk } \\
\text { Trika ruk } \\
\text { Vasti ruk } \\
\text { Vanksana ruk } \\
\text { Udara vipatana } \\
\text { Jirne prakopa } \\
\text { Ahata adhmata } \\
\text { percussion) }\end{array}$ & $\begin{array}{c}\text { voiding of large mass of retained } \\
\text { faeces) }\end{array}$ \\
\hline
\end{tabular}

Other relevant symptoms pertaining to gastro intestinal impairement

Kantha sosa (dryness in throat)

Asya sosa (dryness in mouth)

Sarva rasagrddhi (desire for substances

having all tastes)

Kantha daha (burning sensation in the throat)

Aruchi (distaste)

Trt (thirst)

Asyopdeha (coating over the muth)

Asya madhurya (sweet taste in the mouth)

Sthivana (spitting)

Vairasya (bad taste)

Trpti (satisfaction)
Katu vaktrata (sensation of acrid or pungent taste in mouth)

Praseka (salivation)

Svarabheda (impairement in the production of sound)

Ksavanthu (sneezing)

Othe symptoms relating to Dhatvagni Paka

Sadana, Sauhityasahata, Balaksaya, Bhrama, moha, harsa, Tandra, santosa, Nindra, gaurava, Romaharsa, Annadvesa, Akrsasyapidaurbalaya, Strisvaharsana, Alasya, Karsya, Sitajvara, Gatrastambha Suchivedhavatvedana, Staimitya, Sweda, jwara and Daha.

SYMPTOMS DESCRIBED IN MODERN MDICINE IN DISEASES OF GASTRO INTESTINAL TRACT.

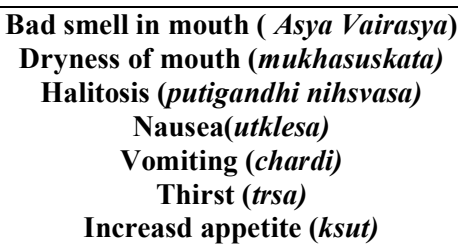

Flatulence in the upper abdomen (udgar urdhva bhaga adhamana) Heart burn (hrt daha)

\section{Headache (sirah shula)}

Depression of spirit (dainya)

Neurasthenia (daurbalya)

Irritability of tempor

Drowsiness (tandra)

Coated tongue (jihva upadeha)

Disturbed sleep (nindra ghata)

Urticarial (sitapitta)

Fullness of stomach (udara gaurava) Paroroxia (desire for unusual food) 


\begin{tabular}{|c|c|}
\hline Acid eructation (amlodgara) & Diarrhea (atisara) \\
Hic cough (Hikka) & Constipation (vistambha) \\
Water brash (lala praseka) & Urinary change (mutra parivartan) \\
Anorexia (anannabhilasha) & Skin change (tvak varna parivartan) \\
Perverted appetite (ksut vaiparitya) & Flatuance (adhaman) \\
General malase (angamarda) & Pain (vedana) \\
A sense of ill health (asvasthya) & Tenderness (sparsaasaha) \\
Incapacity for work (alsaya) & Vomiting (chardi) \\
Dark rim beneath the eye (akshikuta krsnata) & Wasting (ksaya) \\
Sallow oe earthy complexion (panduta) & Pyrexia (jwara) \\
Emaciation (dhauksaya) & Profuse haemorrhage (atiraktasrava) \\
Palpitation (hrt dravatva) & Anaemia (pandu) \\
Dyspnea (svasakrcchra) & Headache (sirahshula) \\
Pre cardial pain (hrdaya vyatha) & Colicky pain (sula) \\
Syncope (murcha sannyasa) & Dry tongue (suksa jihva) \\
Vertigo (bhrama) & Mental confusion (moha) \\
& Fatigue (srama) \\
& Sleeplessness (nindranas) and other \\
\hline
\end{tabular}

\section{CONCLUSION}

Jatharagni and Dhatwagni i.e are the Ansh of Kayagni is responsible for Amotapatti, which leads to the manifestation of disorders of Jatharagni as well as Dhawagni. We can say that the Agni Dushti may leads to various types of Vyadhi (disease). So, primarily it is important to treat the Agni Dushti, if Agni will be treated then it is easy for the physician to treat further disorders because Agni Dushti is the root cause of the diseases. Roga Sarve Api Mandeganau- Acharya Vagbhata said that Mandagni is responsible for the origination of maximum diseases and through this review article it is seen that Agni Dushti can be the causative factors behind any disease. So Agni is play most important role in Swastha and Aturavastha of the body.

\section{REFERENCE}

1. Charak Samhita (As precepted by the great sage Atreya Punarvasu) of
Agnivesa elaborated by Caraka and redacted by Drdhabala (volume 1), by Dr. Brahmanand Tripathi, published by Chaukhambha Surbhartee PrakashanVaransi, printed-2013, Sutra Sthan, Adhyay- 12, Slok-11, Page No.-259.

2. Sushruta Samhita of Maharsi - Susruta edited with Ayurveda-Tattva-Sandipika by Kaviraja Ambikadutta Shastri, (part 1) published by Chaukhambha Sanskrit Sansthan- Varansi, printed-2015, Sutra Sthan Adhyay-21, Slok - 5, page No. 112.

3. Charak Samhita (As precepted by the great sage Atreya Punarvasu) of Agnivesa elaborated by Caraka and redacted by Drdhabala (volume 1), by Dr. Brahmanand Tripathi, published by Chaukhambha Surbhartee PrakashanVaransi, printed-2013, Sutra Sthan, Adhyay- 30, Slok-28, Page No.-567.

4. Charak Samhita (As precepted by the great sage Atreya Punarvasu) of 
Agnivesa elaborated by Caraka and redacted by Drdhabala (volume 1), by Dr. Brahmanand Tripathi, published by Chaukhambha Surbhartee PrakashanVaransi, printed-2013, Sutra Sthan, Adhyay- 12, Slok-11, Page No.-259.

5. Shreemad-Vagbhatta Virachita Asthanghradayam, by Dr. Brahmanand Tripathi, published by Chaukhamba Sanskrit Pratishthan - Delhi, printed2012, Sutra Sthan, Adhyay - 12, Shlok 11, Page No.- 172.

6. Shreemad-Vagbhatta Virachita Asthanghradayam, by Dr. Brahmanand Tripathi, published by Chaukhamba Sanskrit Pratishthan - Delhi, printed2012, Sutra Sthan, Adhyay - 12, Shlok 11, Page No.- 172.

7. Shreemad-Vagbhatta Virachita Asthanghradayam, by Dr. Brahmanand Tripathi, published by Chaukhamba Sanskrit Pratishthan - Delhi, printed2012, Sutra Sthan, Adhyay - 12, Shlok 10, Page No.- 172.

8. Shreemad-Vagbhatta Virachita Asthanghradayam, by Dr. Brahmanand Tripathi, published by Chaukhamba Sanskrit Pratishthan - Delhi, printed2012, Sutra Sthan, Adhyay - 11, Shlok 34, Page No.- 166.

9. Charak Samhita (As precepted by the great sage Atreya Punarvasu) of Agnivesa elaborated by Caraka and redacted by Drdhabala (volume 2), by Dr. Brahmanand Tripathi, published by Chaukhambha Surbhartee PrakashanVaransi, printed-2013, Chikitsa Sthan, Adhyay- 15, Slok-39, Page No.-558.

10. Sushruta Samhita of Maharsi - Susruta edited with Ayurveda-Tattva-Sandipika by Kaviraja Ambikadutta Shastri, (part 1) published by Chaukhambha Sanskrit Sansthan- Varansi, printed-2015, Sutra Sthan Adhyay-21, Slok - 10, page No. -115 .

11. Charak Samhita (As precepted by the great sage Atreya Punarvasu) of Agnivesa elaborated by Caraka and redacted by Drdhabala (volume 1), by Dr. Brahmanand Tripathi, published by Chaukhambha Surbhartee PrakashanVaransi, printed-2013, Sutra Sthan, Adhyay- 11, Slok-48, Page No.-246.

12. Shreemad-Vagbhatta Virachita Asthanghradayam, by Dr. Brahmanand Tripathi, published by Chaukhamba Sanskrit Pratishthan - Delhi, printed2012, Sutra Sthan, Adhyay - 9, Shlok 20, Page No.- 166.

13. Shreemad-Vagbhatta Virachita Asthanghradayam, by Dr. Brahmanand Tripathi, published by Chaukhamba Sanskrit Pratishthan - Delhi, printed2012, Sutra Sthan, Adhyay - 13, Shlok 25, Page No.- 188 
14. . Shreemad-Vagbhatta Virachita Asthanghradayam, by Dr. Brahmanand Tripathi, published by Chaukhamba Sanskrit Pratishthan - Delhi, printed2012, Sutra Sthan, Adhyay - 13, Shlok 26, Page No.- 188.

15. Charak Samhita (As precepted by the great sage Atreya Punarvasu) of Agnivesa elaborated by Caraka and redacted by Drdhabala (volume 2), by Dr. Brahmanand Tripathi, published by Chaukhambha Surbhartee PrakashanVaransi, printed-2013, Chikitsa Sthan, Adhyay- 15, Slok-42-43, Page No.-559.

16. Sushruta Samhita of Maharsi - Susruta edited with Ayurveda-Tattva-Sandipika by Kaviraja Ambikadutta Shastri, (part 1) published by Chaukhambha Sanskrit Sansthan- Varansi, printed-2015, Sutra Sthan Adhyay-46, Slok - 535, page No. -291 .

17. Sushruta Samhita of Maharsi - Susruta edited with Ayurveda-Tattva-Sandipika by Kaviraja Ambikadutta Shastri, (part 1) published by Chaukhambha Sanskrit Sansthan- Varansi, printed-2015, Sutra Sthan Adhyay-46, Slok - 535, page No. -291. 